\title{
Design, Analysis and Optimization of a Solar Dish/Stirling System
}

\author{
Seyyed Danial Nazemi ${ }^{\mathrm{a}}$ and Mehrdad Boroushaki ${ }^{\mathrm{b}}$
}

\author{
${ }^{a}$ Master of Science Student in Energy Systems Engineering, Sharif University of Technology, Tehran, P.0.Box 14565-114, Iran \\ ${ }^{b}$ Associate Professor of Department of Energy Engineering, Sharif University of Technology, Tehran, P.O.Box 14565-114, Iran
}

\begin{abstract}
In this paper, a mathematical model by which the thermal and physical behavior of a solar dish/Stirling system was investigated, then the system was designed, analysed and optimized. In this regard, all of heat losses in a dish/Stirling system were calculated, then, the output net-work of the Stirling engine was computed, and accordingly, the system efficiency was worked out. These heat losses include convection and conduction heat losses, radiation heat losses by emission in the cavity receiver, reflection heat losses of solar energy in the parabolic dish, internal and external conduction heat losses, energy dissipation by pressure drops, and energy losses by shuttle effect in displacer piston in the Stirling engine. All of these heat losses in the parabolic dish, cavity receiver and Stirling engine were calculated using mathematical modeling in MatlabTM software. For validation of the proposed model, a $10 \mathrm{~kW}$ solar dish/Stirling system was designed and the simulation results were compared with the Eurodish system data with a reasonable degree of agreement. This model is used to investigate the effect of geometric and thermodynamic parameters including the aperture diameter of the parabolic dish and the cavity receiver, and the pressure of the compression space of the Stirling engine, on the system performance. By using the PSO method, which is an intelligent optimization technique, the total design was optimized and the optimal values of decision-making parameters were determined. The optimization has been done in two scenarios. In the first scenario, the optimal value of each designed parameter has been changed when the other parameters are equal to the designed case study parameters. In the second scenario, all of parameters were assumed in their optimal values. By optimization of the modeled dish/Stirling system, the total efficiency of the system improved to $0.60 \%$ in the first scenario and it increased from $21.69 \%$ to $22.62 \%$ in the second scenario of the optimization, while the system variables changed slightly.
\end{abstract}

Keywords: Dish/Stirling System; Heat losses; Thermal model; Total efficiency; Optimization

Article History: Received Sept 28, 2015; Received in revised form January 08, 2016; Accepted February 15, 2016; Available online

How to Cite This Article: Nazemi, S. D. and Boroushaki, M. (2016) Design, Analysis and Optimization of a Solar Dish/Stirling System. Int. Journal of Renewable Energy Development, 5(1), 33-42. http://dx.doi.org/10.14710/ijred.5.1.33-42

\section{Introduction}

Reduction of fossil fuels at a rapid rate and increasing of its price make necessary the emergence of green power markets. Furthermore, because of the increased worldwide demand for decentralized power generation systems, the opportunities for small power systems are increasing rapidly. One of the most efficient solar power generation systems that is targeted for applications in this emerging markets is dish/Stirling technology.

Concentrating solar power systems utilize the heat generated by concentrating and absorbing the sun's energy to drive an engine/generator and produce electric power. A solar dish/Stirling system consists of a parabolic dish concentrator, a thermal receiver, a Stirling engine and a power generator located at the focus of the dish to generate power.

A dish/Stirling system tracks the sun and concentrates solar energy into its canon. This energy is transferred to a solar receiver which absorbs and conveys this thermal energy to the Stirling engine. In this system, the parabolic dish uses a two-axis tracking system to maintain a zero incidence angle. The cavity receiver in dish/Stirling systems is responsible to absorbing solar radiation reflected by the concentrator and transferring this energy as heat to the working fluid. The most efficient receivers for this system are cavity receivers with a small aperture through which concentrates entered sunlight. The absorber is placed behind the aperture to reduce the intensity of concentrated solar flux. The isolated cavity between the aperture and absorber reduces the amount of heat loss. Increasing receiver aperture will increase the concentrated sunlight. On the other hand, it also increases radiation and convection losses. Consequently, there is a trade-off between the effect of input heat to the receiver and heat losses.

"Corresponding author: +98(21)66166102;

Email: boroushaki@sharif.edu 
Citation: Nazemi, S. D. and Boroushaki, M. (2016) Design, Analysis and Optimization of a Solar Dish/Stirling System. Int. Journal of Renewable Energy Development, 5(1), 33-42, doi : 10.14710/ijred.5.1.33-42

P a g e $\mid 34$

In a solar dish/Stirling system, Stirling engine has an important contribution in the whole system. High efficiency, high power density, low maintenance operation and the potential for long-term use make the Stirling engines the most preferred engines for these solar systems. An elementary Stirling engine is comprised of a compression piston, an expansion piston, and three heat exchangers: a cooler, a heater, and a regenerator.

The engine uses external combustion; consequently, it can produce mechanical work by any source of energy, especially solar energy. In the past years, there are many authors who worked on Stirling engines and their heat losses. However, there are a few works which focused on optimizing their output work and efficiency. The Stirling engine performance depends on its working fluid and thermodynamic and physical design, such as regenerator efficiency, dead volumes, swept volumes, the temperature of sources, pressure drop and energy and shuttle losses.

Kalogirou (2004) worked on the different types of solar thermal collectors and applications. It is mentioned that use of some tracking systems improves the efficiency of solar collectors because it makes them maintain a zero incidence angle. Stine and Harrigan (1985) considered optical errors of tracking systems as typical errors in moving solar concentrators. Harris and Lenz (1985) studied the influence of cavity's geometry and the rim angle of the concentrator on the temperature profile of the cavity. Nepveu et al. (2009) investigated a nodal method for calculating the energy losses by reflection, convection, and conduction through the ceramic walls. Beltran et al. (2012) presented a mathematical model to design a dish/cavity system. Sendhil and Reddy (2007) have shown a numerical investigation of natural convective losses in a receiver cavity at a particular inclination. Sendhil and Reddy (2008) also worked a fuzzy focal solar dish concentrator which uses three different cavity receivers. Fraser (2008) investigated the radiation emitted by the cavity. In his work, by considering view factors, he calculated the effective absorbance and the aperture area.

With considering to energetic similarity, Scollo et al. (2008) proposed a new design of Stirling engine. Popescu et al. (1996) worked on improving the nonadiabatic regenerator in order to increase the performance of the engine. Kongtragool and Wongwises (2003) presented a literature review on the technology of low-temperature differential Stirling engines and use of Stirling engines in solar power systems. Martini (1978) has identified several heat losses, such as dissipation by pressure drop, conduction losses in the heat exchangers, and some other dissipation by gas spring hysteresis. Urieli and Berchowitz (1984) have developed a quasi-steady model. In this model, they only focused on the pressure drop in the heat exchangers. Kongtragool and Wongwises (2006) worked on the effect of regenerator efficiency on the input heat and engine efficiency. Tlili et al. (2008) have proposed a novel design of Stirling engine. Their design was very helpful for use of Stirling engine in solar systems. Timoumi et al. (2008) have also presented an optimization based on a model which is used to determine all of heat losses which occurs in different parts of the engine.

In this article, a mathematical model for designing and analysing of a solar dish/Stirling system is proposed. Then, a $10 \mathrm{~kW}$ system will be designed and the result of this system will be compared with the results of the Eurodish system. Moreover, using PSO algorithm, the designed system will be optimized. The main goal of this work is to present a general method for calculating all of heat losses in solar dish/Stirling system and developing a designing tool for optimization of this system.

\section{Methodology of the designed dish/Stirling system}

A solar dish/Stirling system which includes a parabolic dish and a power conversion is shown schematically in Fig. 1. In this article, the solar part of the system which comprise a concentrator and a cavity receiver is investigated. With considering the heat losses by radiation and reflection in the concentrator and conduction, convection and radiation in the receiver, the output energy from the cavity receiver to the Stirling engine is calculated.

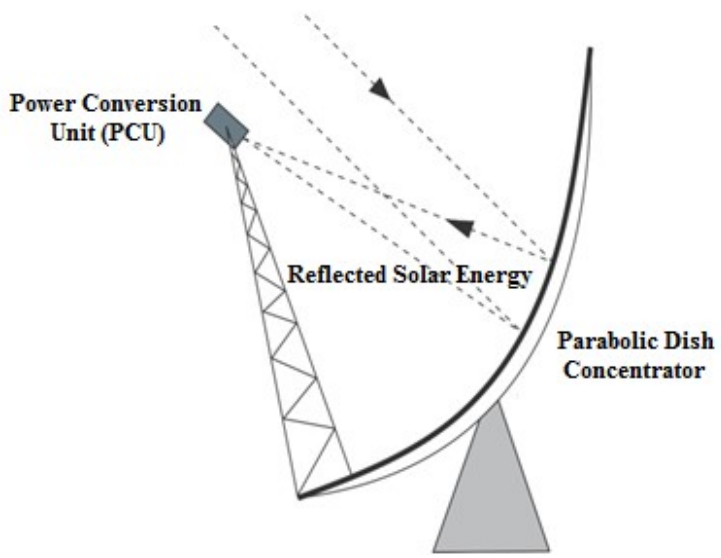

Figure 1 Dish/Stirling system components: solar collector and Power Conversion Unit (PCU), which includes receiver, Stirling engine and generator

For the analysis of the engine, the adiabatic model which has been developed by Tlili et al. (2008) is used. In the proposed model, with considering the input heat to the engine and heat losses in it, the output work is calculated. In the Stirling engine, the most important section to analyse is to calculate the heat losses in the engine. These heat losses include three main parts, the internal and external conduction, the energy dissipation by pressure drops, and the heat losses by shuttle effect. To validate this model, the results are compared with 
the GPU-3 engine data. Finally, the model results are compared with the Eurodish system results (Nepveu et al. 2009, Mancini et al. 2003).

Finally, by using PSO method, which is an intelligent optimization technique, the total efficiency of the system will be optimized and the system of equations is solved for the variables thermodynamic properties of the working fluid of the engine and physical parameters of the concentrator and the receiver.

\section{Parabolic dish and cavity receiver mathematical model}

In the present work, a mathematical model is used to design and analyse parabolic dish and cavity receiver. The output heat from cavity receiver to the heater of Stirling engine is calculated using this model. In this part, all of heat losses in these two units are worked out. Then, by computation of concentrated heat, the transferred heat from the receiver to the engine has been calculated.

\subsection{Thermal model}

The heat transferred to the Stirling engine is:

$$
\dot{Q}_{\text {eng }}=\dot{Q}_{\text {dish }}-\dot{Q}_{\text {ref } 1}-\left(\dot{Q}_{\text {cond }}+\dot{Q}_{\text {conv }}+\dot{Q}_{\text {rad }}\right)
$$

where the beam radiation $\dot{Q}_{\text {dish }}$ entering the cavity receiver is:

$$
\dot{Q}_{d i s h}=I \cdot A_{d i s h} \rho_{d i s h} \varphi
$$

where $I$ is the direct solar radiation $\left(W \cdot m^{-2}\right), \rho_{\text {dish }}$ is the reflectance of the concentrator and $\varphi$ is the interception factor. The radiation reflected back from the cavity receiver is calculated as Duffie and Beckman (2006):

$\dot{Q}_{r e f 1}=\left(1-\frac{\alpha_{r e c}}{\alpha_{r e c}+\left(1-\alpha_{r e c}\right)\left(A_{a p} / A_{r e c}\right)}\right) \dot{Q}_{d i s h}$

The conduction heat losses through the insulation are dissipated by convection can be calculated by:

$$
\dot{Q}_{\text {cond }}=\frac{T_{a b s}-T_{a m b}}{\frac{L_{\text {ins }}}{k_{\text {ins }} A_{\text {rec }}}+\frac{1}{h_{\text {exit }, \text { rec }} A_{\text {rec }}}}
$$

The total convection heat losses from the inner walls of the cavity can be represented by:

$$
\dot{Q}_{c o n v}=h_{T} A\left(T_{a b s}-T_{a m b}\right)
$$

To calculate the total heat transfer coefficient by convection, we need to calculate the heat transfer coefficient by natural convection $h_{\text {nat }}$ and the heat transfer coefficient produced by wind speed considering the inclination of the receiver $h_{\text {wind }}$. The radiation heat losses by emission are calculated with the model proposed by Incropera and DeWitt (2002):

$$
\dot{Q}_{\text {rad }}=\varepsilon_{\text {rad }} \sigma A_{a p}\left(T_{a b s}^{4}-T_{a m b}^{4}\right)
$$

Where $A_{a p}$ is a function of the aperture diameter and $\sigma$ is Stefan-Boltzman constant. The efficiency of the parabolic dish is equal to reflectance of the surface of the concentrator (Beltran et al. 2012) and the efficiency of the receiver is given by:

$\eta_{\text {rec }}=\frac{\dot{Q}_{\text {eng }}}{\dot{Q}_{\text {dish }}}$

The total efficiency of the system can be represented by:

$\eta_{T}=\eta_{\text {dish }} \eta_{\text {rec }} \eta_{\text {eng }} \eta_{\text {gen }}$

Where $\eta_{\text {dish }}, \eta_{\text {rec }}, \eta_{\text {eng }}$ and $\eta_{\text {gen }}$ are the efficiency of the parabolic dish, cavity receiver, Stirling engine and electricity generator, respectively.

\subsection{Method of Solution of dish/cavity equations}

The Parabolic dish and cavity receiver model which is used in this article has been calculated using the abovementioned equations. After working out of the heat which is entering the cavity receiver and optical and thermal losses, heat losses can be calculated by these two methods. First, from the general energy balance on the receiver, the total energy losses can be represented as:

$$
\dot{Q}_{l o s s 1}=\dot{Q}_{d i s h}-\dot{Q}_{r e f l}-\dot{Q}_{e n g}
$$

Second, it can be calculated by summing all the contributions to the total heat loss:

$\dot{Q}_{\text {loss } 2}=\dot{Q}_{\text {cond }}+\dot{Q}_{\text {conv }}+\dot{Q}_{\text {rad }}$

In this method, the goal is to calculate the output heat from the receiver. After these calculations, if the difference between these losses is less than an arbitrary amount, in this article it is taken 1 Watt, the transferred heat to the engine in the final iteration will be the answer. Otherwise, calculations should be continued until the difference meets the specified condition. 
Citation: Nazemi, S. D. and Boroushaki, M. (2016) Design, Analysis and Optimization of a Solar Dish/Stirling System. Int. Journal of Renewable Energy Development, 5(1), 33-42, doi : 10.14710/ijred.5.1.33-42

$\mathrm{P}$ a g e $\mid 36$

\section{Stirling engine mathematical model}

Stirling engine is an engine which is worked on a closed regenerative thermodynamic cycle using a working gas such as hydrogen or helium. The working gas is expanded and compressed in different processes at various temperatures. Many works presented various thermal models to approximate the real behavior of this engine. In the present article, the goal of this model is to calculate the output work of the engine. In this regard, with considering the input heat from receiver $\left(Q_{e n g}\right)$ and calculating all of heat losses in different parts of the engine, which are shown in Fig. 2, the output power is worked out. The quantity of heat losses in each part of engine will be presented in the following sections.

\subsection{Heat losses in Stirling engine}

The heat losses considered in this model consist of energy dissipation by pressure drops, conduction heat losses and the shuttle effect in the displacer.

The internal heat generation which occurs when the gas is forced to flow against the frictional drag force is given by:

$$
d \dot{Q}_{s h t l}=-\frac{\Delta p \cdot \dot{m}}{\rho}
$$

where $\Delta \mathrm{p}$ is pressure drops due to friction and to area changes in heat exchangers, $m$ is the mass flow rate and $\rho$ is gas density. The total heat generation by pressure drops in the different heat exchangers is equal to sum of the heat dissipation in each heat exchanger. Energy loss due to internal conduction between the hot parts and the cold parts of the engine through the heat exchangers are taken into account. These losses are given for each heat exchanger as follows:

$$
d \dot{Q}_{\text {cond }, i}=k_{i} \frac{A_{i}}{L_{i}}\left(T_{\text {exit }}-T_{\text {inlet }}\right)
$$

Where $\mathrm{k}$ is the thermal conductivity of the materials, $A$ is the effective area for conduction heat transfer, $T_{\text {exit }}$ and $T_{\text {inlet }}$ are the exit and inlet temperatures of the fluid in each heat exchanger, respectively. All of the temperatures are shown in Figure 2(a).

The displacer shuttles between hot and cold spaces within a machine and transfers heat from a hot to a cold space. The displacer absorbs a specific value of heat from the hot source and conveys it to the cold source. This loss of energy is given by:

$$
d \dot{Q}_{s h t l}=\frac{0.4 Z^{2} k_{p i s} D_{d i s p}}{J \cdot L_{d i s p}}\left(T_{d}-T_{c}\right)
$$

Where $\mathrm{J}$ is the annular gap between the displacer and the cylinder(m), $k_{p i s}$ is the thermal conductivity of the piston $\left(\mathrm{W} . \mathrm{m}^{-1} \mathrm{~K}^{-1}\right), D_{\text {disp }}$ is the displacer diameter $(\mathrm{m})$, $L_{\text {disp }}$ is the displacer length $(\mathrm{m}), \mathrm{Z}$ is the displacer stroke(m) and $T_{d}$ and $T_{c}$ are the temperature in the expansion space and in the compression space, respectively (K).
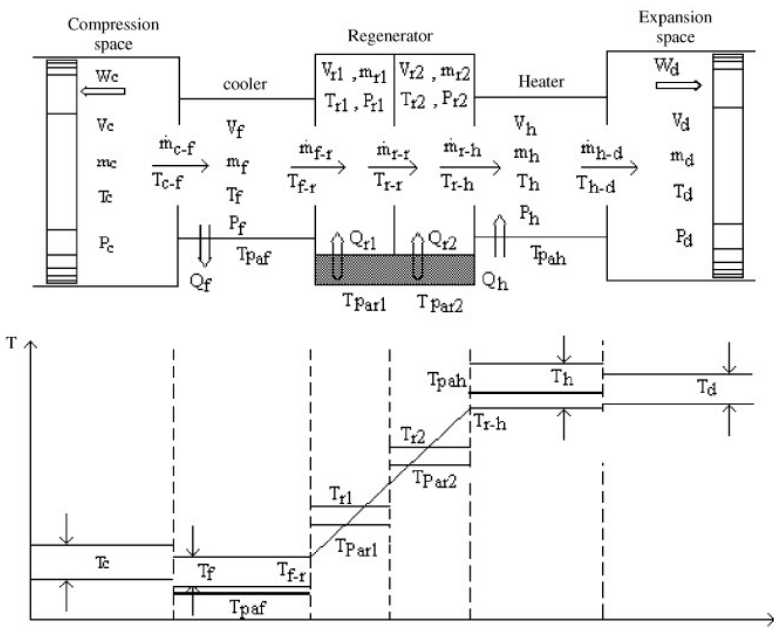

Figure 2. (up) Schematic model of the Stirling engine; (down) temperature distribution in the Stirling engine (Tlili et al. 2008, Timoumi et al. 2008).

\subsection{Mathematical modeling of the Stirling engine}

The mathematical model takes into consideration different losses and pressure drops in heat exchangers. The dynamic model of the developed Stirling engine is based on the following assumptions (Tlili et al. 2008):

(1) Gas temperature in the different engine elements varies linearly,

(2) There is no leakage. The total mass of gas in the system being constant,

(3) The temperature of the cooler and the heater walls are constant and their values are $T_{p a f}$ and $T_{p a h}$ respectively,

(4) Gas temperature in the different components is calculated according to the perfect gas law.

(5) Regenerator divided into two cells which are named $r_{1}$ and $r_{2}$; the mixed mean gas temperatures of each cell are $T_{r 1}$ and $T_{r 2}$, respectively. To define the regenerator interface temperatures $T_{r-f}, T_{r-r}$ and $T_{r-h}$, temperature values $T_{r 1}$ and $T_{r 2}$ should be extrapolated.

By taking into account the flow direction of the fluid, another interface temperatures: $T_{c-f,} T_{f-r}, T_{r-h}$ and $T_{h-d}$ are defined as follows (Popescu et al. 1996):

If $\dot{m}_{c-f}>0$, then $T_{c-f}=T_{c}$, otherwise $T_{c-f}=T_{f}$;

If $\dot{m}_{f-r}>0$, then $T_{f-r}=T_{f,}$, otherwise $T_{f-r}=T_{r-f}$;

If $\dot{m}_{r-h}>0$, then $T_{r-h}=T_{r-h}$, otherwise $T_{r-h}=T_{h}$;

If $\dot{m}_{h-d}>0$, then $T_{h-d}=T_{h,}$ otherwise $T_{h-d}=T_{d}$.

The heat exchanged in the different heat exchangers, by considering to the conduction loss in the heat exchangers and the regenerator effectiveness, are given by: 


$$
\begin{aligned}
& d \dot{Q}_{f}=h_{f} A_{p a_{f}}\left(T_{p a f}-T_{f}\right)-d \dot{Q}_{c o n d, f} \\
& d \dot{Q}_{r 1}=\varepsilon_{r} h_{r 1} A_{p a_{r}}\left(T_{p a r}-T_{r 1}\right)-d \dot{Q}_{c o n d, r 1} \\
& d \dot{Q}_{r 2}=\varepsilon_{r} h_{r 2} A_{p a_{r 2}}\left(T_{p a r 2}-T_{r 2}\right)-d \dot{Q}_{c o n d, r 2} \\
& d \dot{Q}_{h}=h_{h} A_{p a_{h}}\left(T_{p a h}-T_{h}\right)-d \dot{Q}_{c o n d, h}
\end{aligned}
$$

where $\varepsilon_{r}$ is the effectiveness of the regenerator and $h$ is the heat transfer coefficient which are only available empirically and $T_{p a r}$ is the regenerator matrix temperature. Furthermore, the total exchanged heat is:

$$
d \dot{Q}=d \dot{Q}_{f}+d \dot{Q}_{r 1}+d \dot{Q}_{r 2}+d \dot{Q}_{h}-d \dot{Q}_{s h t l}
$$

And the work given by the cycle is:

$$
\frac{d W}{d t}=P_{c} \frac{d V_{c}}{d t}+P_{d} \frac{d V_{d}}{d t}
$$

By applying energy equation to a generalized cell, the next equation is reproduced:

$$
d \dot{Q}+C_{p} T_{i} \dot{m}_{i}-C_{p} T_{e} \dot{m}_{e}=P \frac{d V_{c}}{d t}+C v \frac{d(m T)}{d t}
$$

A baseline pressure should be chosen to compute the values of the other points' pressures. In this article, the compression space pressure $P_{c}$ was chosen. Hence, at each iteration of the solution, this value will be calculated and as a result, the pressure distribution will be evaluated respect to $P_{c}$. The pressure variation is obtained by applying energy conservation equation to the different engine cells and summing these equations:

$$
\frac{d P_{c}}{d t}=\frac{1}{C_{v} V_{T}}\left[R\left(d \dot{Q}-d \dot{Q}_{\text {diss }}\right)-C_{p} \frac{\delta W}{d t}\right]
$$

The efficiency of the Stirling engine is given by:

$$
\eta_{\text {eng }}=\frac{\dot{W}}{\dot{Q}_{\text {eng }}}
$$

where $\dot{Q}_{\text {eng }}$ is the entered heat to the Stirling engine which is provided by solar collection system.

\subsection{Method of solution of the Stirling engine}

The independent differential equations which are obtained in Eq. 17 and Eq. 18, are solved simultaneously. This system of differential equations is solved by the classical fourth-order Runge-Kutta method, cycle after cycle until periodic conditions are reached. The vector $Y$ denotes the unknown function. For example, $Y_{P c}$ is the gas pressure in compression space. The objective is to find the unknown function $Y(t)$ which satisfies both the differential equations and the initial conditions (Tlili et al. 2008, Timoumi et al. 2008).

\section{A designed case study}

In this article, a solar dish/Stirling system was

\begin{tabular}{|c|c|c|c|}
\hline & & $\begin{array}{l}\text { Designed } \\
\text { system }\end{array}$ & Eurodish \\
\hline \multirow{3}{*}{$\begin{array}{l}\text { Operational } \\
\text { Conditions }\end{array}$} & $\mathrm{DNI}\left(\mathrm{W} / \mathrm{m}^{2}\right)$ & 900 & 906 \\
\hline & $\begin{array}{l}\text { Absorber } \\
\text { temperature }(\mathrm{K})\end{array}$ & 1045 & 1120 \\
\hline & $\begin{array}{l}\text { Ambient } \\
\text { temperature }(\mathrm{K})\end{array}$ & 305 & 293 \\
\hline \multirow{4}{*}{$\begin{array}{l}\text { Parabolic dish } \\
\text { parameters }\end{array}$} & $\begin{array}{l}\text { Dish aperture } \\
\text { diameter }(\mathrm{m})\end{array}$ & 8.5 & 8.5 \\
\hline & Reflectance & 0.925 & 0.92 \\
\hline & Rim angle & $45^{\circ}$ & $45^{\circ}$ \\
\hline & $\begin{array}{l}\text { Total error of solar } \\
\text { collector }\left(\mathrm{m}_{\mathrm{rad}}\right)\end{array}$ & 8 & 8 \\
\hline \multirow{3}{*}{$\begin{array}{l}\text { Cavity receiver } \\
\text { parameters }\end{array}$} & $\begin{array}{l}\text { Cavity outside } \\
\text { diameter }(\mathrm{m})\end{array}$ & 0.275 & 0.26 \\
\hline & $\begin{array}{ll}\text { Cavity } & \text { receiver } \\
\text { aperture } & \text { diameter } \\
(\mathrm{m}) & \end{array}$ & 0.19 & 0.18 \\
\hline & $\begin{array}{l}\text { Inclination angle of } \\
\text { the cavity receiver }\end{array}$ & $40^{\circ}$ & $40^{\circ}$ \\
\hline \multirow{3}{*}{$\begin{array}{l}\text { Stirling engine } \\
\text { parameters }\end{array}$} & Working fluid & Hydrogen & Hydrogen \\
\hline & Angular speed (rpm) & 1500 & 1500 \\
\hline & $\begin{array}{l}\text { Range of the } \\
\text { pressure of the } \\
\text { working gas (bar) }\end{array}$ & $40-130$ & $40-130$ \\
\hline \multirow[b]{2}{*}{ Final results } & Output power $(\mathrm{kW})$ & 10.41 & 10.81 \\
\hline & $\begin{array}{l}\text { Total efficiency of the } \\
\text { system (\%) }\end{array}$ & 21.69 & 22.5 \\
\hline
\end{tabular}
designed using the proposed model. Table 1 compares the designed system parameters with the Eurodish system parameters (Reinalter et al. 2006) as the reference plan. Both of these systems produce $10 \mathrm{kWe}$ as their output power. These results are obtained considering the weather of Tehran, Iran.

Table 1

Comparing the designed 10kWe dish/Stirling system with Eurodish

The aim of definition of this case study is to compare the proposed model results with the Eurodish system results. By using the aforementioned case study and proposed model, the results are validated, and then, all of heat losses, energy efficiency, and total output work of the dish/Stirling system at different numbers of direct normal insolation (DNI) and temperature are presented.

\section{Validation of the mathematical model}

In order to validate the present mathematical model of dish/Stirling system, the results which are obtained in the model were compared with experimental results reported by Reinalter et al. (2006) for Eurodish system which was operated on the 
Citation: Nazemi, S. D. and Boroushaki, M. (2016) Design, Analysis and Optimization of a Solar Dish/Stirling System. Int. Journal of Renewable Energy Development, 5(1), 33-42, doi : 10.14710/ijred.5.1.33-42

$\mathrm{P}$ a g e $\mid 38$

Plataforma Solar de Almeria in Spain. Operation conditions and data of case study are similar to Eurodish system and it is given in Table 2 .

Table 2

Eurodish specifications used for validation of the mathematical model

\begin{tabular}{ll}
\hline Parameters & Value and material \\
\hline DNI & $906 \mathrm{~W} / \mathrm{m}^{2}$ \\
Dish diameter & $8.5 \mathrm{~m}$ \\
Cavity receiver diameter & $0.25 \mathrm{~m}$ \\
Pressure of the engine & $40-130 \mathrm{bar}$ \\
Ambient temperature & $293 \mathrm{~K}$ \\
Rim angle & $45^{\circ} \mathrm{C}$ \\
Working fluid & Helium \\
\hline
\end{tabular}

For being similar operating conditions for comparing the results, all of them are assumed in the operating conditions of the Eurodish system (Nepveu et al. 2009). The comparison of the present mathematical model with that of the experimental case of Reinalter et al. (2006) is illustrated in Table 3. It can be seen that the present model reveals reasonable agreement with the experimental data.

Table 3

Comparison of the modeled system with Eurodish solar energy dispatching

\begin{tabular}{|c|c|c|c|}
\hline Parameters & $\begin{array}{l}\text { Eurodish } \\
\text { energy } \\
\text { dispatching } \\
\text { (\%) }\end{array}$ & $\begin{array}{l}\text { Model energy } \\
\text { dispatching } \\
\text { (\%) }\end{array}$ & $\begin{array}{l}\text { Design } \\
\text { difference } \\
(\%)\end{array}$ \\
\hline Dish reflection & 7.5 & 7.5 & 0.0 \\
\hline Spillage & 13.9 & 13.1 & -0.8 \\
\hline $\begin{array}{l}\text { Conduction losses in } \\
\text { the receiver }\end{array}$ & 1.1 & 1.9 & +0.8 \\
\hline $\begin{array}{l}\text { Convection losses in } \\
\text { the receiver }\end{array}$ & 3.7 & 3.2 & -0.5 \\
\hline $\begin{array}{l}\text { Radiation losses by } \\
\text { emission in the } \\
\text { receiver }\end{array}$ & 9.4 & 10.5 & +1.1 \\
\hline $\begin{array}{l}\text { Internal conduction } \\
\text { in the engine }\end{array}$ & 13.8 & 14.2 & +0.4 \\
\hline $\begin{array}{l}\text { External conduction } \\
\text { in the engine }\end{array}$ & 18.2 & 17.8 & -0.4 \\
\hline $\begin{array}{l}\text { Shuttle effect in the } \\
\text { engine }\end{array}$ & 2.8 & 2.7 & -0.1 \\
\hline $\begin{array}{l}\text { Energy dissipation by } \\
\text { pressure drop in the } \\
\text { engine }\end{array}$ & 5.2 & 4.9 & -0.3 \\
\hline $\begin{array}{l}\text { Electrical dissipation } \\
\text { and consumption }\end{array}$ & 2.9 & 2.6 & -0.3 \\
\hline Output Electricity $^{*}$ & 22.5 & 21.7 & -0.8 \\
\hline
\end{tabular}

\section{Dish/Stirling system simulation results}

Figure 3 shows the effect of the aperture diameter of the cavity receiver on total thermal losses in the receiver and heat transferred to the engine. In the aperture diameter of cavity equals to $0.29 \mathrm{~m}$, heat transferred to the Stirling engine is maximized; while with the increase of the aperture diameter of cavity, total thermal losses in receiver is increased, proportionally.

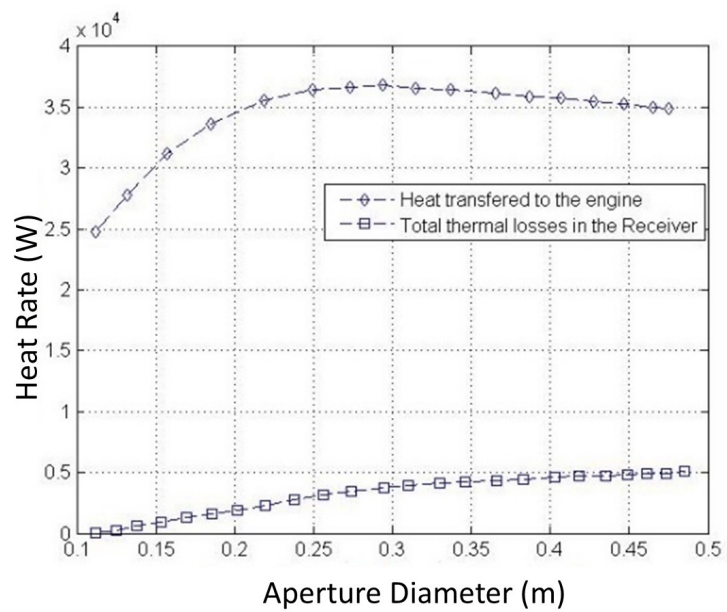

Figure 3 The influence of aperture diameter of the cavity receiver on the heat transferred to the engine and total thermal losses in the cavity

Fig. 4 shows all of the heat losses in the Stirling engine. The heat flow lost by internal conduction, the energy dissipated by pressure drops through the heat exchangers and the shuttle heat loss in the displacer are given. The heat loss caused by internal conduction in the regenerator is about $8.3 \mathrm{~kW}$, and the energy loss caused by internal conduction in the cooler and heater are negligible. The energy lost due to dissipation is mainly observed in the regenerator which has an average of $1 \mathrm{~kW}$. The average heat loss caused by the shuttle effect is about $3.6 \mathrm{~kW}$.

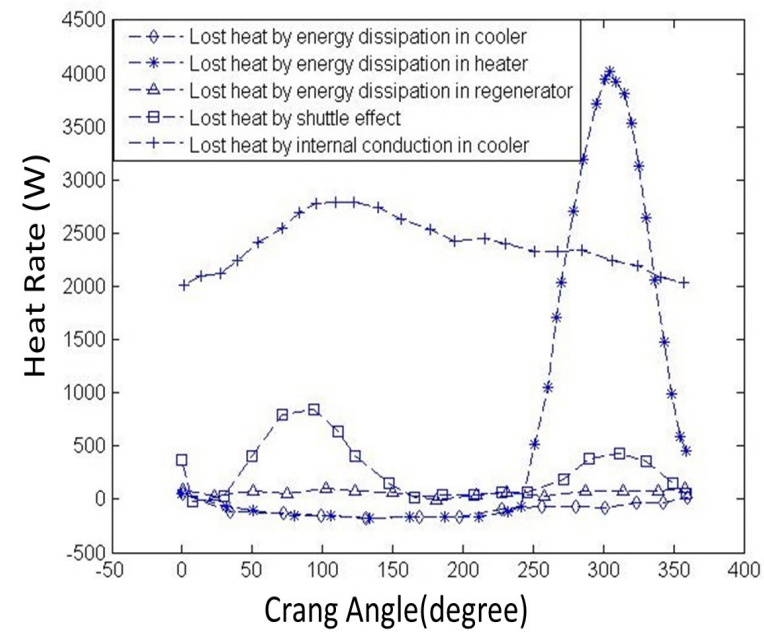

Figure 4 Heat losses in the Stirling engine 


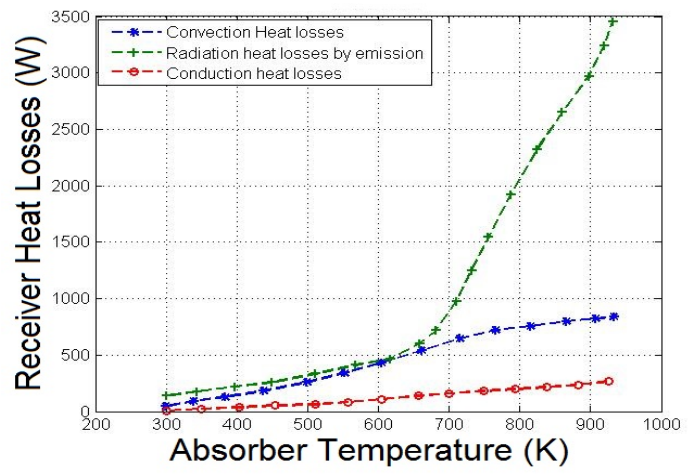

Figure 5 Heat losses in the cavity receiver

The thermal losses in the cavity receiver are shown in Fig. 5. It reveals that increasing the absorber temperature $T_{a b s}$ will increase all of the thermal losses. After the absorber temperature reaches $625 \mathrm{~K}$, a rapid increase in the radiation heat loss rate can be observed because the effect of emission of radiation heat loss becomes greater.

Fig. 6 shows the influence of the absorber temperature on the efficiency of the solar collection system, interception factor $\varphi$ and total convective heat transfer coefficient $h_{T}$. This figure reveals that in a specific absorber temperature, about $830 \mathrm{~K}$, efficiency of the receiver $\eta_{\text {rec }}$ and efficiency of the solar collection system, which includes dish and cavity receiver, are maximized. In this work, the efficiency of the parabolic dish $\eta_{\text {dish }}$ has been assumed constant (Beltran et al. 2012). By increasing the amount of the absorber temperature, the amount of interception factor gets close to unity. Increasing the absorber temperature makes Nusselt number greater than before and as a result increase in the natural convection heat transfer coefficient $h_{\text {nat }}$. This causes increase in the amount of total convection heat transfer coefficient $h_{T}$.

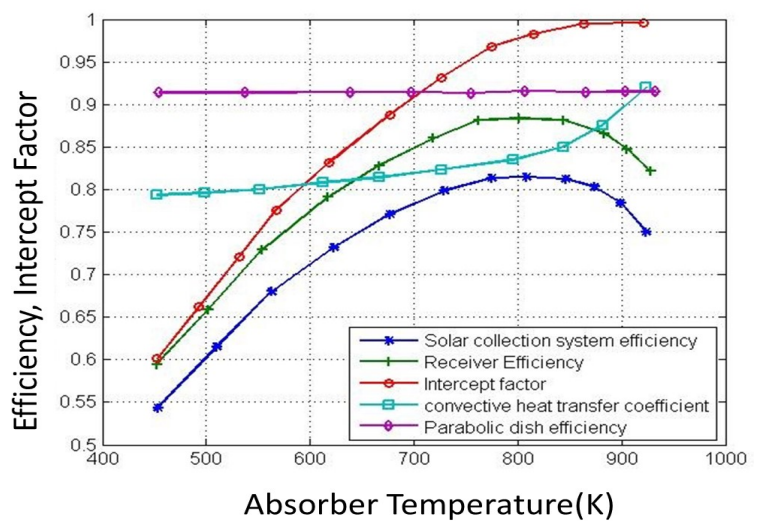

Figure 6 The influence of the absorber temperature on the efficiency of the solar collection system, interception factor and total convective heat transfer coefficient

Fig. 7 reveals that by increasing the difference between the temperature of hot and cold sources, the output power and the efficiency of the engine are increased. According to the experimental data which is reported by Mancini et al. (2003), the most heat loss in the dish/Stirling system is happening in the Stirling engine. Therefore, it is important to know the influence of the difference between hot and cold source on the efficiency of the Stirling engine.

Fig. 8 shows the influence of the mean pressure of the Stirling engine on the output power and efficiency of the engine. This figure reveals that if the mean pressure of the working fluid of the Stirling engine is increased, the output power of the engine and engine efficiency will be increased.

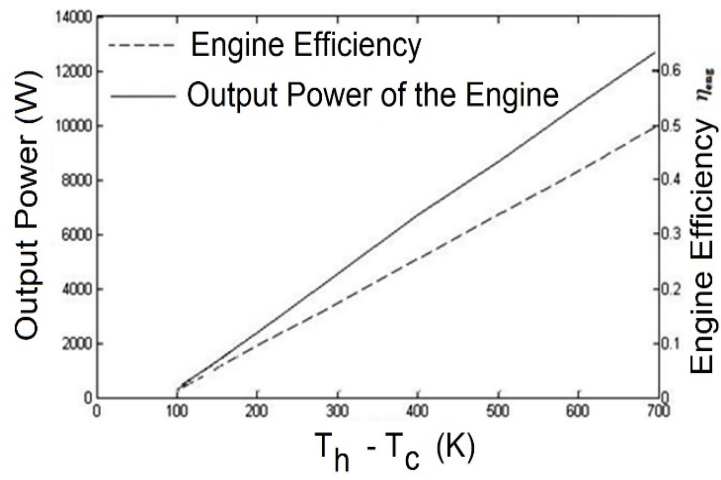

Figure 7 The influence of difference between heat and cold source of the Stirling engine on the output power and efficiency of the engine

In the forthcoming case study of this model, output power is about $11 \mathrm{~kW}$, it means the mean pressure of the Stirling engine should be selected about 53 bar and engine efficiency should be $40 \%$.

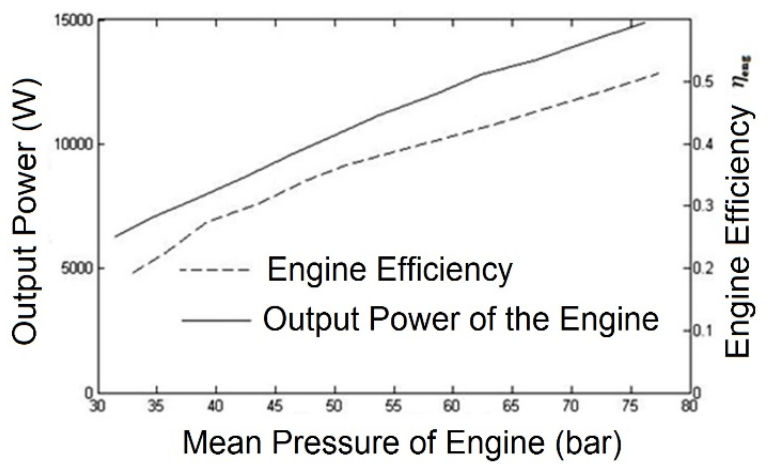

Figure 8 The influence of the mean pressure of the Stirling engine on the output power and efficiency of the engine

The influence of the absorber temperature on the output power and total efficiency of the system in different DNIs and different ambient temperatures are shown in Fig. 9 and Fig. 10, respectively. As expected, it can be observed that the increase in direct normal insolation (DNI) directly influences on the output power and efficiency of the dish/Stirling system. However, by increasing the absorber temperature after $800 \mathrm{~K}$, efficiency of the system shows a slow increase. Fig. 10 reveals that in lower ambient temperature, the output power, and total efficiency are greater. However, it 
Citation: Nazemi, S. D. and Boroushaki, M. (2016) Design, Analysis and Optimization of a Solar Dish/Stirling System. Int. Journal of Renewable Energy Development, 5(1), 33-42, doi : 10.14710/ijred.5.1.33-42

$\mathrm{P}$ a g e $\mid 40$

needs very specific conditions to have low ambient temperature and high absorber temperature.

Increasing the DNI will increase the output power and total efficiency of system. Fig. 11 and Fig. 12 show how the change of DNI and diameter of the cavity receiver and dish influence on the output power and total efficiency of the system. It can be observed when the dish diameter is set to $8.16 \mathrm{~m}$, the output power and total efficiency reach the optimal amount. In the forthcoming case study, optimal output power and efficiency at $900 \mathrm{~W} / \mathrm{m}^{2}$ are $10.8 \mathrm{~kW}$ and $30 \%$, respectively.

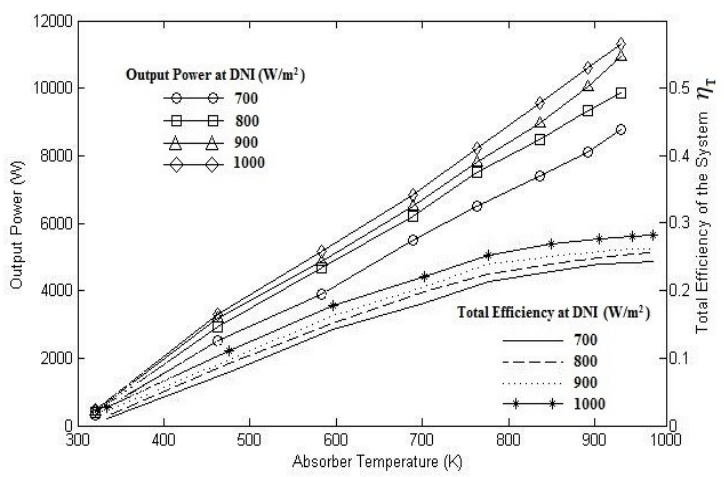

Figure 9 The influence of DNI and absorber temperature on the output power and total efficiency of the dish/Stirling system

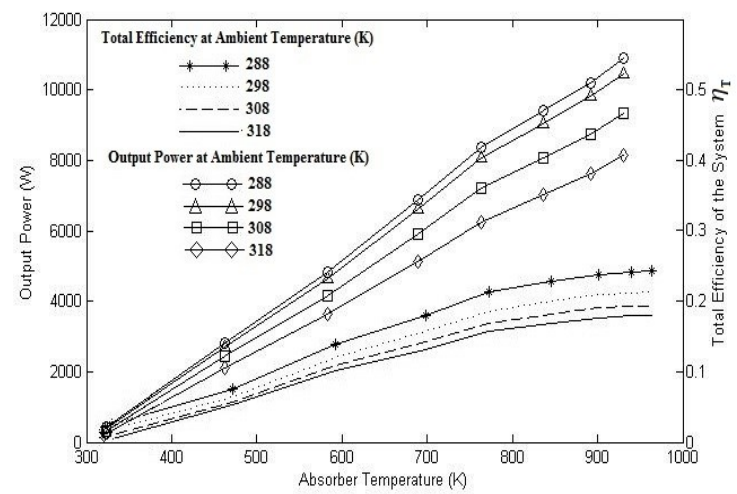

Figure 10 The influence of ambient and absorber temperature on the output power and total efficiency of the dish/Stirling system

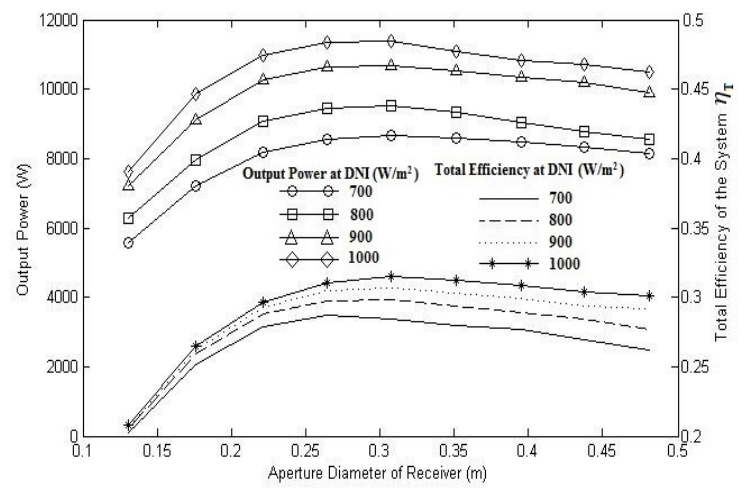

Figure 11 The influence of DNI and aperture diameter of the cavity receiver on output power and total efficiency of the dish/Stirling system

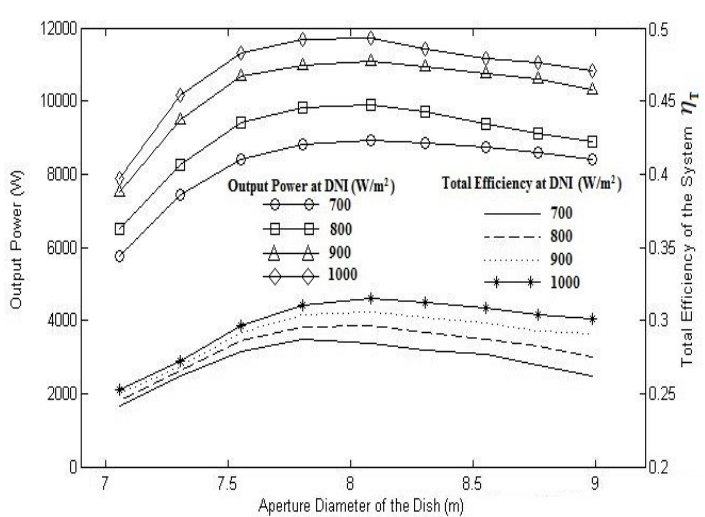

Fig 12 The influence of DNI and aperture diameter of the parabolic dish on output power and total efficiency of the dish/Stirling system

\section{Optimization of the presented design by using PSO algorithm}

The aim of the optimization in this design is to maximize the value of total efficiency of the dish/Stirling system $\left(\eta_{T}\right)$. For implementing the PSO algorithm in the designed dish/Stirling system, at first, particles with appropriate dimensions have to be selected. In the PSO algorithm, each particle has a Ddimensional vector, where $\mathrm{D}$ is the number of optimized parameters and in this implementation, $\mathrm{D}$ is equivalent to 3 , the aperture diameter of parabolic dish, the aperture diameter of cavity receiver, and the pressure of the compression space of the Stirling engine. Then, several runs have been done with various values of the PSO main parameters such as the initial inertia weight and the maximum allowable velocity. The initial inertia weight $w(0)$ and the number of particles $\mathrm{n}$ are selected 1.0 and 60, respectively. Moreover, $c_{1}$ and $c_{2}$ are identical and their values are equal to 2 .

Table 4

Optimization results of dish/Stirling design with PSO algorithm in the first scenario

\begin{tabular}{lllll}
\hline Parameters & $\begin{array}{l}\text { Optimal } \\
\text { Value }\end{array}$ & $\begin{array}{l}\text { Output } \\
\text { Power }\end{array}$ & $\begin{array}{l}\text { Total } \\
\text { Efficiency }\end{array}$ & $\begin{array}{l}\text { Efficiency } \\
\text { Enhancement }\end{array}$ \\
\hline $\begin{array}{l}\text { Aperture } \\
\text { diameter of } \\
\text { the cavity } \\
\text { receiver }\end{array}$ & $0.1841 \mathrm{~m}$ & $10.63 \mathrm{~kW}$ & $22.15 \%$ & $0.46 \%$ \\
$\begin{array}{l}\text { Aperture } \\
\text { diameter of } \\
\text { the parabolic } \\
\text { dish }\end{array}$ & $8.5913 \mathrm{~m}$ & $10.69 \mathrm{~kW}$ & $22.29 \%$ & $0.60 \%$ \\
$\begin{array}{l}\text { The pressure } \\
\text { of the } \\
\text { compression } \\
\text { space of the } \\
\text { engine }\end{array}$ & $124.12 \mathrm{bar}$ & $10.57 \mathrm{~kW}$ & $22.02 \%$ & $0.33 \%$ \\
$\begin{array}{l}\text { Model result } \\
\text { before } \\
\text { optimization }\end{array}$ & & $10.41 \mathrm{~kW}$ & $22.69 \%$ & \\
$\begin{array}{l}\text { Experimental } \\
\text { result }\end{array}$ & & $10.81 \mathrm{~kW}$ & $22.5 \%$ & \\
\hline
\end{tabular}


Each particle updates itself based on the fitness function of total efficiency $\left(f(x)=h_{T}\right)$. The search will be terminated if the convergence condition is met. The convergence condition is acquired when: $\eta_{T}(n)-\eta_{T}(n-$ 1) $\leq 0.01$ for at least 10 consecutive iterations. The optimization has been done in two scenarios. In the first scenario, the optimal value of each designed parameter has been changed when the other parameters are equal to the designed case study parameters. The results of the first scenario of the optimization are presented in Table 4. This table reveals that the efficiency of the system can be improved up to $0.60 \%$. In the second optimization scenario, all the designed parameters of the designed case study have been changed simultaneously. Fig. 13 shows the variation of the total efficiency in this scenario.

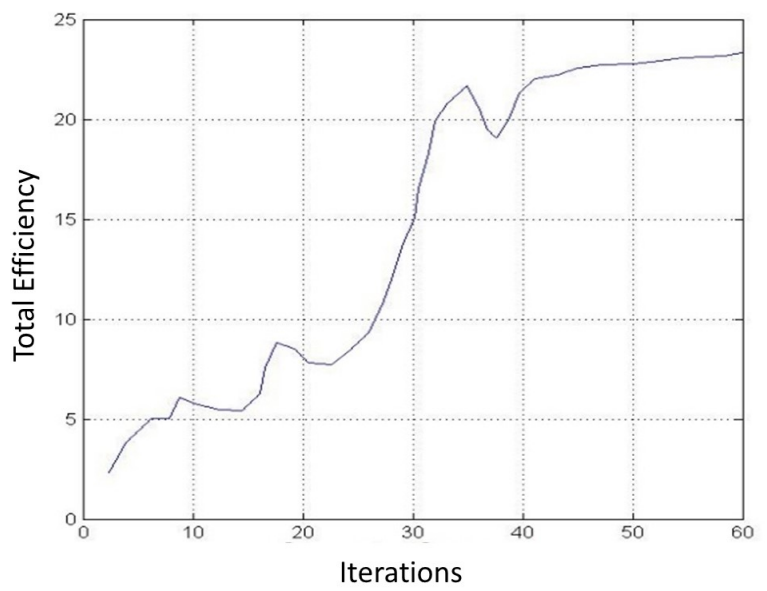

Figure 13 The total efficiency of the dish/Stirling system versus iterations, during the PSO optimization

In the second scenario, the aperture diameter of the parabolic dish, the aperture diameter of the cavity receiver and the pressure of the compression space of the Stirling engine are equal to $8.6331 \mathrm{~m}, 0.1909 \mathrm{~m}$ and 126.07 bar, respectively. With considering to these values for the selected parameters, the total efficiency of the system increased to $22.62 \%$ which shows $0.93 \%$ enhancement (Table 5).

Tabel 5

Optimization results of dish/Stirling design with PSO algorithm in the second scenario

\begin{tabular}{ll}
\hline Parameters & $\begin{array}{c}\text { Optimal } \\
\text { Value }\end{array}$ \\
\hline Aperture diameter of the cavity receiver & $0.1909 \mathrm{~m}$ \\
Aperture diameter of the parabolic dish & $8.6331 \mathrm{~m}$ \\
The pressure of the compression space of the engine & $127.07 \mathrm{bar}$ \\
$\begin{array}{l}\text { The total efficiency of the system in second } \\
\text { optimization scenario }\end{array}$ & $22.62 \%$ \\
$\begin{array}{l}\text { Output power of the system in second optimization } \\
\text { scenario }\end{array}$ & $10.86 \mathrm{~kW}$ \\
\hline
\end{tabular}

\section{Conclusion}

A mathematical model for a dish/Stirling system was proposed and the system was designed, analysed and optimized. To validate the results, a solar dish/Stirling system, which was completely similar to the Eurodish system, was designed and analysed using the proposed model and then, the results of the simulated system were compared with experimental results of the Eurodish system. Through this mathematical model, an easy and complete method was developed for designing and optimizing a dish/Stirling system.

Simulation results show a considerable heat loss in Stirling engine and cavity receiver. In the Stirling engine, these losses consist of pressure drops in the regenerator, the shuttle effect in the displacer piston, and external and internal conduction. In the cavity receiver, heat losses consist of radiation loss by emission, convection and conduction losses. These losses are minimized and the output power and total efficiency are maximized using PSO algorithm. By designing a system with optimal values which is presented in Table 5, the total efficiency of the system increases to $22.62 \%$.

The results of this research should be implemented to a real design to investigate the validation of the results. In addition, applying the proposed approach to prototypes is a good idea, because it may lead to the determination of the optimal design parameters and as a result increase in the performance of the system. Moreover, the search for greater efficiency must investigate the economic issues which are a necessary decision-making parameter to manufacture the solar dish/Stirling systems.

\section{References}

Beltran, R., Velazquez, N., Espericueta, A. C., Sauceda, D., Perez, G. (2012) Mathematical model for the study and design of a solar dish collector with cavity receiver for its application in Stirling engines, Journal of Mechanical Science and Technology 26 (10) 3311-3321.

Duffie, J. A. \& Beckman, W. A. (2006) Solar engineering of thermal processes, 3rd edition, John Wiley and Sons.

Fraser, P. R. (2008) Stirling dish system performance prediction model, Master's Thesis, University of Wisconsin-Madison.

Harris, J. A. \& Lenz, T. G. (1985) Thermal performance of solar concentrator/cavity receiver systems, Solar Energy, 34, 135142.

Incropera, F. P. \& DeWitt, D. P. (2002) Fundamentals of heat and mass transfer, 5 th edition, John Wiley and Sons.

Kalogirou, S. A. (2004) Solar thermal collectors and applications, Progress in Energy and Combustion Science, 30, 231-295.

Kongtragool, B. \& Wongwises, S. (2003) A review of solar-powered Stirling engines and low temperature differential Stirling engines, Renewable and Sustainable Energy Reviews, 7, 131-154.

Kongtragool, B. \& Wongwises, S. (2006) Thermodynamic analysis of a Stirling engine including dead volumes of hot space, cold space and regenerator, Renewable Energy, 31, 345-359.

Mancini, T., Heller, P., Butler, B., Osborn, B. (2003) Dish-Stirling systems: An overview of development and status, Solar Energy Engineering, 125, 135-151

Martini, W. R. (1978) Stirling engine design manual, NASA CR-135382. 
Citation: Nazemi, S. D. and Boroushaki, M. (2016) Design, Analysis and Optimization of a Solar Dish/Stirling System. Int. Journal of Renewable Energy Development, 5(1), 33-42, doi : 10.14710/ijred.5.1.33-42

P a g e 42

Nepveu, F., Ferriere, A., Bataille F. (2009) Thermal model of a dish/Stirling systems, Solar Energy, 83, 81-89.

Popescu, G., Radcenco, V., Costea, M., Feidt, M. (1996) Thermodynamic optimization in the finished time of Stirling engines, Rev Gen Therm, 35, 656-661.

Reinalter, W., Ulmer, S., Heller, P., Rauch, T., Gineste, J. M., Ferriere, A., Nepveu, F. (2006) Detailed performance analysis of $10 \mathrm{~kW} C N R S$ PROMES dish/Stirling system. In: Proceedings of the 13th SolarPACES International Symposium, Seville, Spain.

Scollo, L., Valdez, P., Baron, J. (2008) Design and construction of a Stirling engine prototype, International Journal of Hydrogen Energy, 33, 3506-3510

Sendhil, K. N. \& Reddy, K. S. (2007) Numerical investigation of natural convection heat loss in modified cavity receiver for fuzzy focal solar dish concentrator, Solar Energy, 81, 846-855.

Sendhil, K. N. \& Reddy, K. S. (2008) Comparison of receivers for solar dish collector systems, Energy Conversion Management, 49, 812-819.
Shi, Y. \& Eberhart, R. (1998) A modified particle swarm optimizer, Proceeding of IEEE international conference on evolutionary computation, 69-73.

Stine, W. B. \& Harrigan, R. W. (1985) Solar energy fundamentals and design with computer applications, New York: Wiley Interscience.

Timoumi, Y., Tlili, I., Ben Nasrallah, S. (2008) Design and performance optimization of GPU-3 Stirling engines, Energy, 33, 1100-1114.

Tlili, I., Timoumi, Y., Ben Nasrallah, S. (2008) Analysis and design consideration of mean temperature differential Stirling engine for solar application, Renewable Energy, 33, 1911-1921.

Urieli, I. \& Berchowitz, D. (1984) Stirling cycle engine analysis, Bristol: Adam Hilger. 